\title{
EFEKTIFITAS KAPSUL MENGKUDU (Morinda citrifolia) TERHADAP PENURUNAN KADAR GULA DARAH PADA PASIEN DIABETES MELLITUS DI RS BRAWIJAYA
}

\author{
Yuni Irianti ${ }^{1}$ dan Dra.Ngadiani,M.Kes ${ }^{2}$ \\ ${ }^{(1)}$ Mahasiswa Prodi Biologi F MIPA Universitas PGRI Adi Buana Surabaya \\ ${ }^{(2)}$ Staf pengajar Prodi Biologi F MIPA Universitas PGRI Adi Buana Surabaya
}

\begin{abstract}
We report the supplementation of noni (Morinda citrifolia) to decrease blood sugar levels in patients with diabetes mellitus Brawijaya Hospital Surabaya, and noni problems whether supplementation is effective in reducing blood sugar levels in diabetes patients mellitus.The goal of this study was to determine the effectiveness of capsule morinda to decrease blood sugar levels in patients with Diabetes Mellitus in Brawijaya Hospital Surabaya.

This type of research is to ekperimem quasi control group design with pre-test and post test. The population in this study are patients with diabetes mellitus in hospital outpatient Brawijaya. The sampling technique with a number of 60 people who were divided into 30 groups of control (can drug from a doctor) and 30 in the experimental group (can medicine from the doctor and consumption of noni capsules) .Instrumen this study is the laboratory results of random blood sugar levels with the tools glucometer ( gluko Dr). Data analysis was performed using univariate and bivariate (parametric test, Kolmogorov-Smirnov test $\mathrm{z}$ and Independent T-Test). From the results, no significant difference the difference in the results of pre-test and post-test in the control group and the experiment is $\mathrm{p}=0.020(<0.05)$, then the alternative hypothesis $(\mathrm{Ha})$ is accepted (the results are meaningful).

It is concluded that supplementation of noni effective in helping to decrease blood sugar levels of patients with diabetes mellitus, it is advisable to consume noni capsules and routine checks of blood sugar levels so that the blood sugar levels under control.
\end{abstract}

Keywords: noni capsules, blood sugar levels

\section{PENDAHULUAN \\ Latar Belakang}

Diabetus mellitus adalah penyakit hiperglikemia yang ditandai oleh ketiadaan absolut insulin atau insensitivitas sel terhadap insulin. Berdasarkan definisi glukosa darah puasa harus lebih besar dari pada $140 \mathrm{mg} / \mathrm{dl}$ pada dua kali pemeriksaan terpisah agar diagnose diabetes mellitus dapat ditegakkan (Elizabeth J.C. 2000:542).

Di Indonesia jumlah penderita diabetes mellitus mencapai 14 juta orang. Dari jumlah tersebut baru $50 \%$ penderita yang sadar melakukan pengobatan secara teratur.Di Surabaya cenderung lebih tinggi, yaitu $6,1 \%$, sedangkan di Jakarta adanya peningkatan prevalensi diabetes mellitus dari $1,7 \%$ pada tahun 1982 menjadi $5,7 \%$ pada tahun 1993 , dan menjadi $12,8 \%$ pada tahun 2001 .

Berdasarkan data rumah sakit tahun 2005 mengenai laporan bulanan penyakit diabetes mellitus pada penderita rawat jalan di RS Brawijaya pada bulan Agustus terdapat 65 penderita $(18,77 \%)$ pada bulan September 107 penderita $(31,38 \%)$ dan bulan Oktober meningkat menjadi 178 penderita (49,85\%) (Lap RS Brawijaya 2005).
Tanaman obat selain sebagai suplemen gizi, juga merupakan tanaman apotek alami, mengandung bahan-bahan yang mirip dengan obatobatan yang dapat mempengaruhi proses pada tubuh termasuk gula darah dan fungsi hormone insulin. Secara umum tanaman obat adalah lebih aman dan lebih murah daripada obat-obatan kimia.

Salah satu tanaman obat yang digunakan sebagai penggobatan alternative untuk penyakit diabetes mellitus adalah mengkudu (Morinda citrifolia).Dalam buah mengkudu terdapat kandungan zat proxeronine dan proxeroninase melalui pembentukkan xeronine yang dapat meregenerasi sel-sel pancreas yang mengalami kerusakan, sehingga sel-sel beta pancreas dapat berfungsi kembali dengan baik dan menghasilkan insulin yang cukup untuk mengendalikan kadar gula dalam darah.

\section{Rumusan Masalah}

Berdasarkan latar belakang diatas,maka dapat dirumuskan masalah yaitu: Apakah kapsul mengkudu dapat efektif dalam menurunkan kadar gula darah pada penderita Diabetes Melitus? 


\section{Tujuan Penelitian}

Adapun tujuan dari penelitian ini adalah :

Mengetahui efektifitas kapsul mengkudu terhadap penurunan kadar gula darah pada pasien Diabetes Mellitus di RS Brawijaya.

\section{Manfaat Penelitian}

Manfaat dari penelitian ini diantaranya adalah :

a. Dapat memberikan informasi mengenai salah satu alternative tanaman obat untuk menurunkan kadar gula darah.

b. Mengetahui informasi tentang pengertian penyakit Diabetes Mellitus.

c. Mengetahui manfaat kapsul mengkudu bagi penderita Diabetes Mellitus.

d. Hasil penelitian dapat dijadikan bahan pertimbangan di RS Brawijaya dalam memanfaatkan kapsul mengkudu untuk mengendalikan kadar gula darah pada penyakit Diabetes Mellitus.

\section{METODE PENELITIAN}

\section{Jenis dan Rancangan Penelitian}

Jenis penelitian yang digunakan adalah penelitian eksperimen laboratorium, yaitu eksperimen yang bertujuan untuk mengetahui suatu gejala atau pengaruh yang timbul, sebagai akibat dari perlakuan tertentu dan menyediakan control sebagai pembanding, yakni mengetahui efektifitas pemberian kapsul mengkudu terhadap penderita Diabetes Mellitus pada pasien yang berobat di RS Brawijaya Surabaya. Dalam mengontrol situasi penelitian menggunakan rancangan tertentu dan atau penunjukkan subyek secara nir acak untuk mendapatkan salah satu dari berbagai tingkat faktor peneliti.(Bhisma Murti, 1997:137).

Dalam hal ini kita lihat perbedaan pencapaian antara kelompok eksperimen (O2 - O1)) dengan pecapaian kelompok control (O2 - O1). Desain penelitian ini dapat digambarkan sebagai berikut :

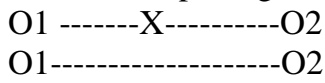

Keterangan :

E : Kelompok yang mendapatkan intervensi perlakuan

$\mathrm{C}$ :Kelompok pembanding (control)

O1 : Pengamatan awal /pertama.

O2 : Pengamatan kedua.

$\mathrm{X}$ : Intervensi (perlakuan) dengan konsumsi kapsul mengkudu.

\section{Sampel Penelitian}

Sampel penelitian ini adalah penderita diabetes mellitus rawat jalan di RS Brawijaya Surabaya.Pada penelitian ini sampel yang diambil sebanyak 60 pasien yang diambil berdasarkan kriteria inklusi dan kreteria eklusi.

Umur antara 30 - 70 tahun.
1. Kadar glukosa darah sewaktu kriteria sedang 125 - $199 \mathrm{mg} / \mathrm{dl}$ dan kreteria buruk adalah $>200 \mathrm{mg} / \mathrm{dl}$.

2. Menggunakan $\mathrm{OHO}$ dengan jenis dan dosis obat sesuai dengan hasil kadar gula darah pasien.

\section{Intrumen Penelitian}

Instrumen adalah tahap untuk mempersiapkan semua bahan dan alat yang dibutuhkan selama penelitian, meliputi :

-Menyediakan 30 kemasan kapsul mengkudu, dengan isi 60 kapsul .

-Menyediakan 6 tube stik glucometer , 1 tube berisi 25 stik ( 3 tube untuk pelaksanaan pre test dan 3 tube untuk pelaksanaan post test ).

- Menyediakan jarum autoclik dan alat autoclik (sampel yang digunakan darah kapiler).

- Menyiapkan kapas dan alcohol 70\%.

- Menggunakan alat Glukometer (Gluco Dr).

- Menyediakan formulir, untuk mencatat hasil pemeriksaan kadar gula darah pasien.diabetes mellitus tanpa mengkonsumsi kapsul mengkudu.

\section{Teknik Pengambilan Sampel}

Teknik pengambilan sampel pemeriksaan dilakukan dengan menggunakan darah kapiler pada ujung jari tangan yang telah didesifektan dengan kapas alkohol dan dilakukan penusukkan dengan jarum autoklik.. Dengan alat gluco Dr hasil pemeriksaan akan terbaca selang 5 detik setelah darah kapiler dimasukkan pada alat. Dan hasil bisa langsung di catat .

\section{HASIL PENELITIAN}

Hasil Uji Statistik Nilai Selisih PreTest dan Post Test Pada Kelompok Kontrol dan Eksperimen

Uji statistik pada penelitian ini adalah melakukan uji Normalitas dan terlebih dahulu dilakukan sebelum melakukan uji hipotesis. Uji Normalitas data

Yang digunakan adalah Kolmogorov-Smirnov Z karena jumlah sampel yang digunakan lebih dari atau sama dengan 50. Data dikatakan normal jika nilai P (Probabilitas) lebih besar dari 0,05.

\section{Uji Normalitas Kolmogo Smirnov}

Dari uji Kolmogorov-Smirnov z didapatkan hasil stastitik sebagai berikut

1. Dari kelompok kontrol (yang hanya konsumsi obat dari dokter) didapat nilai 0,387

2. Dari kelompok eksperimen (yang konsumsi obat dari dokter dan minum kapsul mengkudu) didapat nilai 0,976 .

Dari data yang telah kita lakukan penelitian table dibawah dengan uji normalitas 
terhadap kadar gula darah dengan menggunakan Uji Kolmogorov-Smirnov $\mathrm{Z}$ dapat disimpulkan hasil pada kontrol sig $=0,387$ lebih besar dari $\mathrm{P}=0,05$ dan hasil pada ekperimen sig $=0,976$ lebih besar dari 0,05 yang artinya data berdistribusi normal, sehingga dapat kita lanjutkan dengan menggunakan Uji Independent T - Test.

\section{Uji Independent T-Test}

Hipotesis :

1. Ho : Kapsul mengkudu tidak efektif terhadap penurunan kadar gula darah pada penderita Diabetes Mellitus.

2. Нa : Kapsul menggkudu efektif terhadap penurunan kadar gula darah pada penderita Diabetes Mellitus

Dasar dari penggambilan keputusan adalah :

1. Hasil Signifiikansi atau Sig (2- tailed) $>0,05$ maka Ho diterima dan $\mathrm{Ha}$ ditolak.

2. Hasil Signifikansi atau Dg (2-tailed) $<0,05$ maka Ho ditolak dan $\mathrm{Ha}$ diterima.(Sopiyudin Dahlan.2008;26).

Dari hasil uji Independen T-Test didapatkan hasil Sig (2-tailed) sebesar 0,020, maka dapat diartikan bahwa uji Efektifitas pemberian kapsul mengkudu terhadap kadar gula darah pasien Diabetes Mellitus Signifikan,

\section{PEMBAHASAN}

Nilai Selisih Kadar gula Darah Pre Test dan Post Test Pada Kelompok Kontrol dan Kelompok Ekperimen

Berdasarkan penelitian data diperoleh hasil signifikansinya atau nilai p pada hasil selisih pretest dan posttest pada kelompok kontrol dan ekperimen adalah 0,020. Karena nilai $\mathrm{p}(\mathrm{p}<0,05)$, maka hipotesis alternative (Ha) diterima yang artinya bahwa terdapat perbedaan yang bermakna antara selisih nilai pre dan post test pada kelompok ekperimen (konsumsi minum kapsul mengkudu) dengan kelompok kontrol (tanpa konsumsi kapsul mengkudu).

Hasil penelitian ini membuktikan bahwa pemberian kapsul mengkudu dengan dosis 1x1/hari dengan tiap kapsul mengandung 500 mg ektrak mengkudu dapat membantu menurunkan kadar gula darah pada penderita Diabetes Mellitus

Kapsul mengkudu mempunyai kandungan kimia dalam kaitanya dengan diabetes, dalam mengkudu mengandung zat kimia xeronine dan proxeronine yaitu salah satu alkaloid penting yang terdapat dalam buah mengkudu. Xeronine dihasilkan juga oleh tubuh manusia dalam jumlah terbatas yang berfungsi untuk mengaktifkan enzimenzim dan mengatur fungsi protein dalam sel. Walaupun buah mengkudu hanya sedikit xeronine, tetapi tetap mengandung bahan-bahan pembentuk (prekusor) xeronine, yaitu proxeronina dalam jumlah besar..Proxeronine adalah sejenis asam koloid yang tidak mengandung gula,assam amino atau asam nukleat seperti koloid-koloid lainya dengan bobot relativif lebih besar., lebih dari 16.000. Apabila mengkonsumsi proxeronine maka kadar xeronine dalam tubuh akan meningkat. Dalam tubuh manusia (usus) enzim proxeroninase dan zat-zat lain akan mengubah proxeronine menjadi xeronine. Fungsi utama xeronine adalah mengatur bentuk dan regidat (kekerasan) proteinprotein spesifik yang terdapat didalam sel. Hal ini penting mengingat bila protein-protein tersebut berfungsi abnormal, maka tubuh kita akan mengalami gangguan kesehatan. (Anita Rahmawati, 2009).

\section{KESIMPULAN DAN SARAN \\ Kesimpulan}

Berdasarkan hasil penelitian ini maka dapat diperoleh suatu kesimpulan bahwa kapsul mengkudu efektif dalam menurunkan kadar gula darah pada penderita Diabetes Mellitus. Hal ini ditunjukkan dengan adanya perbedaan yang signifikan pada kadar gula darah antara pasien yang mengkonsumsi kapsul mengkudu dengan yang tidak.

\section{Saran}

Bagi penderita diabetes mellitus khususnya yang berobat di RS Brawijaya disarankan untuk mengkomsumsi kapsul mengkudu (Morinda citrifolia ) Dan rutin melakukan pemeriksaaan kadar gula darah agar gula darahnya tetap stabil atau normal.

\section{DAFTAR PUSTAKA}

A.P Bangundan B. Sarwono, 2002, Khasiat dan Manfaat Mengkudu Jakarta:Agro Media Pustaka

Askandar Tjokroprawiro, 2002, Hidup Sehat dan Bahagia Bersama Diabetes, Jakarta: Gramedia Pustaka Utama.

Atah Margiyanti, 2003, Manfaat Sari Buah Mengkudu Dalam Menurunkan Kadar Glukosa Darah, UNNES.

Bart Smet, 1994, Psikologi Kesehatan, Jakarta: PT. Gramedia.

Basuki. (2009). Penata laksanaan Diabetes Mellitus Terpadu. Jakarta: Balai Penerbit FKUI.

Bilous. (2003). Bimbingan Dokter pada Diabetes Mellitus. Jakarta: Dian.

Bhisma Murti, 1995, Prinsip dan Metode Riset Epidemiologi, Yogyakarta: UGM Press

Brunner \& Suddart. (2002). Buku Ajar Keperawatan Medikal Bedah. Vol. 2, Edisi 8, Jakarta: Penerbit Buku.

Dripa , 2002, Mengkudu, Jakarta Salemba Medika. 
Depkes RI. (2003). Direktorat Keperawatan Dan Keteknisan Medic, Dasar-dasarAsuhan Kebidanan. Jakarta.

Djojodibroto. (2004). Tradisi kehidupan akademik, Jakarta: Galang Press.

ElizabethJ. C. (2009). Buku Saku Patofisiologi. Edisi Revisi Ke-3. Jakarta: EGC.

Elvina Karyadi, 2002,Kiat Mengatasi Penyakit Diabetes, Hiperkolesterolemia, Stroke, Jakarta: PT. Gramedia.

Fox \& Kilvert. (2010). Bersahabat dengan DiabetesWaluyo. Jakarta: Penebar Plus.

Ganong. (2003). Fisiologi Kedokteran. Yogyakarta: Gadjah Mada University Press.
Hans Tandra, 2007, Diabetes, Jakarta: PT. Gramedia.

Harrison, 2000,Prinsip Ilmu Penyakit Dalam, Jakarta: EGC.

Kedokteran EGC Corwin. (2009). Handbook of Pathophysiology, 3rd ed. LippincottWilliams \& Wilkins: USA.

Misnadiarly,2006, Diabetes Mellitus: Gangren, Ulcer, Infeksi, Jakarta: Pustaka PopulerObor

PB Persada,2004, Simposium Diabetes Melltus Untuk Dokter dan Diabetesis, Semaranag CV Agung

Sarwono Waspadji, 2014, Pedoman Diit Diabetes Mellitus, Jakarta: BalaiPenerbit FKUI . 